Ann. Biol. anim. Bioch. Biophys., 1979, 19 (5), 1599-1611.

\title{
Morphological evaluation of bovine embryos recovered non-surgically from superovulated dairy cows on days $61 / 2$ to $71 / 2$ : A field study
}

\author{
par T. GREVE, H. LEHN-JENSEN, N. O. RASBECH \\ Institute for Animal Reproduction, Royal Veterinary and Agricultural University \\ Bülowsvej 13, DK-1870 Copenhagen V, Denmark.
}

Summary. Ninety-two dairy cows milking $23 \mathrm{I}$ milk/day at the time of superovulation and belonging to the main domestic breeds were used in this study. Their mean age was 5.5 years and they had calved a mean 3.6 times. In 71 animals the previous calving interval was 369 days, and the calving-superovulation interval was 126 days. The cows were superovulated with 1500 to 3000 IU of PMSG (mean of $2400 \mathrm{IU}$ ) on days 8 to 13 of the estrous cycle (mean of 10.7 days), followed 48 to $60 \mathrm{hrs}$ (mean of $52 \mathrm{hrs}$ ) later by cloprostenol treatment $(0.5 \mathrm{mg})$. The mean interval from PMSG injection to heat was 4.1 days, and that from the cloprostenol treatment was $45.5 \mathrm{hrs}$. A total of $6.0 \mathrm{embryos} /$ donor were nonsurgically recovered at the farm on days 6 to 8 (mean of 7.1 days). They were evaluated under a stereomicroscope and divided into the following groups : a) embryos with the appropriate (expected) age (developmental stage), showing no signs of degeneration, lysis or swollen blastomers (vacuolization) and including compacted morulae, early expanding blastocysts, expanded blastocysts and rarely hatched blastocysts ; 54.2 p. 100 of the total material (or 3.3 embryos per donor) were classified in this group ; $b$ ) retarded embryos which were at an earlier stage than expected and constituted 5.8 p. 100 of the total material, (or 0.35/donor) ; c) obviously degenerated embryos (morulae or early expanded blastocysts) ; this group was the second largest, comprising 23.7 p. 100 of the total material (or 1.4 embryos/donor) ; d) unfertilized eggs which constituted a minor part (16.3 p. 100 , or 0.88 /donor). The number, quality and distribution of these groups were examined at various dose levels of PMSG and also in the right and left horns. Stimulation with $3000 \mathrm{IU}$ yielded more embryos than 2000 and $2500 \mathrm{IU}$ (6.9 vs 5.9 and 5.8), but 2000 and $2500 \mathrm{IU}$ yielded a significantly higher number of viable embryos than did $3000 \mathrm{IU}$. A significantly higher number of embryos was found in the right uterine horn (7/donor) than in the left horn $2.9 /$ donor). Corresponding to this, there was also a higher number of corpora lutea in the right than in the left ovary (4.1 vs. 3.7). Several batches of PMGS were employed, but no batch variation in embryo quality or number was found. PMSG injection on various days of the cycle produced the following mean number of embryos per donor : injection on day $9: 5.1$ embryos (3.2 A), on day $10: 6.5$ (4.0 A), on day 11: $6.6(2.8 \mathrm{~A})$, on day $12: 7.9(4.7 \mathrm{~A})$, and on day $13: 6.1(3.1 \mathrm{~A})$. We also wished to determine if the interval between PMSG treatment and estrus would influence the number, quality and relative distribution of embryos per donor 3.5 days $(9.6$ embryos) appeared to be more effective than 4 days ( 5.6 embryos) or 4.5 days ( 4.2 embryos). In only 4 donors the interval was 5.0 days and the mean number of embryos was 10.0 . Sixty animals $(71$ p. 100) came in heat between 37 and $48 \mathrm{hrs}$ after the cloprostenol treatment and a total of 6.0 embryos was recovered $(3.3 \mathrm{~A})$. Ten animals $(11.8 \mathrm{p}$. 100) exhibited standing heat from 24 to $36 \mathrm{hrs}$ after the injection with a total of 7.5 embryos (4.1 A) per donor. Twelve cows (14.1 p. 100) showed estrus 49 to $60 \mathrm{hrs}$ after the cloprostenol treatment, and only 3.9 embryos $(1.7 \mathrm{~A})$ were recovered. A small number (3) animals came into heat after $61 \mathrm{hrs}$. The exact time of heat was subject to human error, but it seemed reasonable to assume that more embryos 
of better quality were recovered when the donors came into heat before $60 \mathrm{hrs}$ after cloprostenol treatment. Breed effect was examined, but no statistical difference was found between the main dairy breeds studied (SDM, Jersey). In a small field study on beef cattle a total of 7.1 embryos (4.0 A) was recovered. Age, parity, previous calving interval,calvingsuperovulation interval and actual milk yiled are currently being assessed, but preliminary investigation has failed to show that they have any specific effect. Morphological assessment of embryonic viability in lactating dairy cattle was very different, and there was marked individual variation between animals and even in the same animal (left vs right horn) as to the number, quality and relative distribution of embryos into the four main groups. Based upon a 3-year study, it is concluded however that the correlation between morphological evaluation and subsequent pregnancy (survival) rate was high.

\section{Introduction.}

A time-consuming, frustrating but very important part of embryo transplantation concerns the assessment of the viability of isolated embryos. Most methods are subjective and consequently contain a certain degree of error. Embryonic viability can be evaluated from the stage of development and the ability to continue development in vitro (Trounson et al., 1976 ; Renard et al., 1977). Certain dye tests have also found application (Kardymovicz, 1972), and Renard et al. (1977) measured embryonic metabolic activity. Morphological evaluation and the subsequent transfer to recipients have been widely used (Shea et al., 1976 ; Renard ef al., 1977 ; Elsden ef al., 1978). Several methods require complex equipment and/or a prolonged period of storage, but rapid, reliable morphological evaluation is the only practical method when working under farm conditions. Very litfle information is available on the embryonic quality of lactating, superovulated dairy cattle, although a proper assessment of embryonic viability has significant impact on the pregnancy rate after surgical and non-surgical transfer. Greve ef al. (1977) and Greve and Lehn-Jensen (1977) have presented preliminary data on Danish dairy cattle, and Brand ef al. (1978) have more recently summarized the results of non-surgical recovery from superovulated, lactating HolsteinFriesian cows. Du Mesnil du Buisson ef al. (1976) inferred that lactation might influence egg quality after superovulation ; Hahn (1977) implied that the age of the donor cow, number of calvings, lactational status and calving interval could have some effect on embryo quality.

During the past 3 years, superovulation and embryo transplantation have been routinely used in several Danish dairy herds; based on a retrospective analysis of these data, this paper analyzes the number and the quality of the embryos. Various factors possibly influencing this number and quality were studied after PMSG stimulation. The description of the embryos is based strictly on a stereomicroscopic evaluation at the time of collection, i.e. on days $61 / 2$ to $71 / 2$, when embryonic evaluation is difficult (Whittingham, 1978).

\section{Material and methods.}

92 lactating dairy cows were used in this study. The average age of the animals was $5.5 \pm 3.1$ years, and parity number was $3.6 \pm 2.0$ calvings per donor. The pre- 
vious calving interval was $369 \pm 39$ days, and the calving-superovulation interval was $126 \pm 84$ days. The mean milk yield at the time of superovulation was $23 \pm 8 \mathrm{~kg} /$ day ; butterfat production in the previous year was $251 \mathrm{~kg}$. All the animals belonged to private farmers and had at least 2 to 3 regular cycles since calving. They were milked twice a day and kept on a normal, balanced feed ration. These parameters were recorded for as many animals as possible in order to examine the effects of these factors on egg quality after ovarian PMSG stimulation.

The cows were superovulated in mid-luteal phase, i.e. on days 9 to 13 , with 1500 to 3000 IU of PMSG * and were given a Cloprostenol ** treatment $(0.5 \mathrm{mg}$ IM) later. They were checked very closely 4 to 5 times daily for external signs of heat, and the approximate time of initiation of standing heat was recorded. The PG-heat interval (hrs) and the PMSG-heat interval (hrs) were computed. The cows were inseminated with deep-frozen semen of good quality 12 to $18 \mathrm{hrs}$ after the onsef of standing heat; insemination was repeated 12 to $24 \mathrm{hrs}$ later, and was rarely carried out 3 times. When possible, 2 straws per insemination were used.

We tried to determine if the dose of semen, i.e. the number of straws/pills, would affect embryo quality, but this analysis was complicated by several factors and was finally omitted.

Embryos were collected non-surgically on the farm 6 to 8 days after superovulatory heat and were identified and isolated under a stereomicroscope. Although embryo assessment was difficult at that stage, they were classified into the following groups (Greve and Lehn-Jensen, 1977 ; Greve, Lehn-Jensen and Rasbech, 1978) :

A) Embryos at the expected developmental stage (proper age) according to heat. These embryos were spherical and symmetrical with no signs of lysis, swelling, vacuolation or degeneration of the blastomeres. At days $61 / 2$ to $71 / 2$ the group comprised compacted morulae, expanding blastocysts, expanded blastocysts, and rarelyhatched blastocysts ;

B) Retarded embryos or embryos at an earlier developmental stage, i.e. 8 to 16 or 16 to 32-cell stage ;

C) Embryos containing obvious signs of degeneration. Blastomere integrity had disappeared and lysis and swelling were noted. Both embryos with the proper age and retarded embryos were classed in this group;

D) Ova.

Following this rapid evaluation, embryos belonging to group A were transferred to synchronized recipients or deep-frozen. Embryos that presumably had an inferior quality (groups B and C) were not transferred, as in other studies (Shea ef al., 1976 ; Elsden ef al., 1978).

\footnotetext{
* Antex $(\mathrm{R})$, Leo Pharmaceutical, Ballerup, Copenhagen ; Folligon(R), Intervet Laboratories.

** Estrumat(R) vet, Kindly supplied by Mr. J. Frederiksen, ICl-Pharma, Copenhagen.
} 


\section{Results and discussion.}

Table 1 summarizes the main results from 92 superovulated, lactating dairy cows stimulated with a mean dose of $2400 \pm 420$ IU of PMSG IM in the mid-luteal phase (day $10.8 \pm 1.5)$ and flushed 6 to 8 days after superovulatory heat $(7.1 \pm 0.7$ days). A total of 6.0 embryos was recovered per donor; 3.3 had reached the expected age

TABLE 1

Number and quality of embryos recovered non-surgically from lactating dairy cows on days $61 / 2-71 / 2(n=92)$

\begin{tabular}{lcccc}
\hline $\begin{array}{c}\text { Total no. of embryos per } \\
\text { donor }\end{array}$ & $\begin{array}{c}\text { Embryos } \\
\text { considered } \\
\text { viable }\end{array}$ & $\begin{array}{c}\text { Retarded } \\
\text { embryos }\end{array}$ & $\begin{array}{c}\text { Degenerated } \\
\text { embryos }\end{array}$ & $\begin{array}{c}\text { Unfertilized } \\
\text { eggs }\end{array}$ \\
\hline $\begin{array}{c}6.0 \pm 0.6 \\
\begin{array}{c}6.0 \\
\text { p. } 100 \text { viable embryo }\end{array}\end{array}$ & $\begin{array}{c}3.3 \pm 0.2 \\
54.2\end{array}$ & $\begin{array}{c}0.3 \pm 0.1 \\
5.8\end{array}$ & $\begin{array}{c}1.4 \pm 0.3 \\
23.7\end{array}$ & $\begin{array}{c}1.0 \pm 0.2 \\
16.3\end{array}$ \\
\hline
\end{tabular}

Values are means \pm SEM.

and showed no signs of degeneration. This group comprised compacted morulae and early expanding or expanded blastocysts without degeneration. As emphasized previously, especially compacted morulae were difficult to evaluate. Brand et al. (1978) stimulated Holstein-Friesian dairy cows with 3000 IU of PMSG and recovered 2.7 normal embryos per donor cow by non-surgical means (days 6 to 8 ). These results are comparable with ours since the breed, lactational status and management conditions are similar to those in Denmark. Lampeter (1977) recovered a total of 5.2 embryos from cows, but did not attempt to classify them using more specific criteria. The fertilization rate of the embryos recovered in this study was 84 p. 100 (5.1 embryo/donor), which was comparable to the results obtained in beef cattle by Church and Shea (1976), but higher than reported in superovulated, lactating dairy cattle by Bouters ef al. (1976) and Hasler (1978). The percentage of retarded embryos we found was 0.9 (6 p. 100). This is considerably lower than reported by Elsden ef al. (1976) (18 p. 100). The embryos initially classed as retarded developed into « expected stage » embryos 24 to 36 hrs later. As reported by Seidel ef al. (1977) citing Hasler, spermatozoa were frequently found in the zona pellucida of unfertilized eggs.

Very little information is available concerning the factors affecting the number and the quality of embryos from lactating dairy cattle kept under intensive farming and management conditions. Most studies have dealt with the parameters influencing the superovulation and fertility rate of beef heifer embryos (Gordon, 1975 ; Sreenan and Beehan, 1976 ; Church and Shea, 1976).

Our past 3-year experiments with embryos from superovulated dairy cows have clearly indicated that embryonic yield varied widely with the individual. Tables 2 to 13 attempt to elucidate any factors that might affect the embryo quality of lactating, stimulated dairy cattle. 
Dose of PMSG. - Since it was anticipated that the dose of PMSG would influence the embryonic yield and possibly the quality of the recovered embryo (Sreenan and Beehan, 1976 ; Newcomb et al., 1977 ; others), various doses were tested (table 2), and although cows receiving $3000 \mathrm{IU}$ of PMSG had a higher embryonic yield

TABLE 2

Number and quality of embryos recovered non-surgically from laciating dairy cows on days $61 / 2-71 / 2$. Effect of dose level of PMSG $(n=89)$

\begin{tabular}{lccc}
\hline PMSG dose level $(\mathrm{IU}) \ldots \ldots$ & 2000 & 2500 & 3000 \\
\hline No. of donors $\ldots \ldots \ldots \ldots$ & 25 & 44 & 20 \\
\hline No. of embryos/donor * $\ldots$ & $5.9 \pm 1.2$ & $5.8 \pm 0.8$ & $6.9 \pm 1.2$ \\
No. of viable embryos $\ldots \ldots$ & $3.1 \pm 0.8$ & $3.4 \pm 0.6$ & $2.9 \pm 0.9$ \\
\hline p. 100 viable embryos $\ldots \ldots$ & 52.5 & 58.6 & 42.0
\end{tabular}

* Values are means $\pm S E M$.

$(6.9 \pm 5.4)$, more viable embryos were recovered when only 2000 and 2500 IU were employed. This agrees with preliminary data from the Institute (Greve and Lehn-Jensen, 1977). More embryos were recovered from the right (2.9/donor) than from the left $(2.6 /$ donor) uterine horn (table 3$)$. These differences were statistically

\section{TABLE 3}

Number and quality of embryos recovered non-surgically from lactating dairy cows on days $61 / 2-71 / 2$. Distribution between left and right horn at various PMSG dose levels

\begin{tabular}{|c|c|c|c|c|c|c|c|c|}
\hline PMSG dose levels (IU) & & 000 & 25 & 500 & 30 & 000 & 2000 & $\begin{array}{l}500 \text { and } \\
000\end{array}$ \\
\hline \multirow{2}{*}{$\frac{\text { No. of donors } \ldots \ldots}{\text { Distribution ....... }}$} & \multicolumn{2}{|r|}{24} & \multicolumn{2}{|c|}{40} & \multicolumn{2}{|c|}{19} & \multicolumn{2}{|c|}{85} \\
\hline & $\begin{array}{l}\text { Left } \\
\text { horn }\end{array}$ & $\begin{array}{l}\text { Right } \\
\text { horn }\end{array}$ & $\begin{array}{l}\text { Left } \\
\text { horn }\end{array}$ & $\begin{array}{l}\text { Right } \\
\text { horn }\end{array}$ & $\begin{array}{l}\text { Left } \\
\text { horn }\end{array}$ & $\begin{array}{l}\text { Right } \\
\text { horn }\end{array}$ & $\begin{array}{l}\text { Left } \\
\text { horn }\end{array}$ & $\begin{array}{l}\text { Right } \\
\text { horn }\end{array}$ \\
\hline $\begin{array}{l}\text { No. of embryos/do- } \\
\text { nor }{ }^{*} \ldots \ldots \ldots \ldots \ldots \\
\text { No. of viable em- } \\
\text { bryos } * \ldots \ldots \ldots \ldots\end{array}$ & $\begin{array}{l}3.1 \pm 0.6 \\
1.6 \pm 0.4\end{array}$ & $\begin{array}{l}3.1 \pm 0.8 \\
1.6 \pm 0.6\end{array}$ & $\begin{array}{l}2.7 \pm 0.4 \\
1.6 \pm 0.2\end{array}$ & $\begin{array}{l}3.8 \pm 0.7 \\
2.3 \pm 0.5\end{array}$ & $\begin{array}{l}3.0 \pm 0.5 \\
1.6 \pm 0.5\end{array}$ & $\begin{array}{l}4.2 \pm 0.6 \\
1.4 \pm 0.5\end{array}$ & $\begin{array}{l}2.9 \pm 0.3 \\
1.6 \pm 0.2\end{array}$ & $\begin{array}{l}3.6 \pm 0.5 \\
1.9 \pm 0.3\end{array}$ \\
\hline p. 100 viable embryos & 51.6 & 52.0 & 59.3 & 61.5 & 53.3 & 33.0 & 55.0 & 53.4 \\
\hline
\end{tabular}

* Values indicate $\overline{\mathbf{x}} \pm$ SEM.

significant (level of 0.05) in contrast to data given by Newcomb et al. (1977), and more ovulations occurred in the right than in the left ovary. The difference between group $A$ embryos in the right vs the left uterine horn was not statistically significant in the $(1.8$ right vs 1.6 in the left). 
Surgical transfer of embryos from animals receiving $2500 \mathrm{IU}$ resulted in a higher pregnancy rate than transfer from cows receiving $3000 \mathrm{IU}$ (table 4). Non-surgical transfers did not follow the same trend.

TABLE 4

Effect of PMSG dose level on pregnancy rate after surgical transfer

\begin{tabular}{ccc}
\hline Dose of PMSG & Transferred embryos & $\begin{array}{c}\text { Pregnant recipients } \\
\text { (p. 100) }\end{array}$ \\
\hline $2500 \mathrm{IU}$ & 47 & $28(57.5)$ \\
$3000 \mathrm{IU}$ & 20 & $6(30.0)$ \\
\hline
\end{tabular}

Day of PMSG injection. - The injection of PMSG in the mid-luteal phase (days 8 to 12) gives a higher number of ovulations than when it takes place on other days (Philippo and Rowson, 1975 ; Church and Shea, 1976 ; others) ; this might influence both embryonic number and quality. The mean injection day in the present study was $10.8 \pm 1.5$. Table 5 shows the effect on embryonic yield of injecting PMSG on days 9 ,

TABLE 5

Number and quality of embryos recovered non-surgically from lactating dairy cows on days $61 / 2-71 / 2$. Effect of day of PMSG injection $(n=83)$

\begin{tabular}{lccccc} 
Day of cycle .......... & 9 & 10 & 11 & 12 & 13 \\
\hline No. of donors ......... & 17 & 20 & 26 & 12 & 8 \\
\hline No. of embryos/donor * . & $5.1 \pm 1.4$ & $6.5 \pm 1.2$ & $6.6 \pm 0.5$ & $7.9 \pm 2.2$ & $6.1 \pm 1.8$ \\
No. of viable embryos * .. & $3.1 \pm 0.9$ & $4.0 \pm 0.8$ & $2.8 \pm 0.7$ & $4.7 \pm 1.5$ & $3.1 \pm 1.6$ \\
\hline p. 100 viagle embryos .... & 60.8 & 61.5 & 42.4 & 59.5 & 50.8
\end{tabular}

*Values indicate $\bar{x} \pm$ SEM.

$10,11,12$ and 13 . The highest number of embryos, including the highest number of viable embryos, was found when the cows were injected on day 12 (7.9 embryos). Day 9 injection gave a significantly lower total number of embryos, but the number of viable embryos was almost identical to that of days 11 and 13 . Day 12 injection gave significantly more viable embryos (4.7) than injection on days 9,10 and 13. Individual variation was considerable, the number was limited, and it did not appear that the various days had any great effect on embryo number and quality.

PMSG-heat inferval. - The interval between PMSG treatment and presumable heat could influence the number of corpora lutea, and consequently the number and quality of the embryos (Sreenan and Beehan, 1976 ; others). The mean PMSG-estrus 
interval was $4.1 \pm 0.4$ days ; table 6 provides more specific data on the influence of 3.5, 4.0, 4.5 and 5.5 days. Although the table is difficult to interpret, the 4.5-day interval (4.2 embryos/donor) appeared inferior to the 3.5 and 4.0-day intervals (9.6 and 5.6 embryos/donor, respectively). Due to the limited number, the 5-day interval was difficult to assess.

TABLE 6

Number and quality of embryos recovered non-surgically from lactating dairy cows on days $61 / 2-71 / 2$. Effect of PMSG treatment-estrus interval $(n=81)$

\begin{tabular}{lcccc} 
PMSG $\rightarrow$ estrus (days) $\ldots \ldots \ldots$ & 3.5 & 4.0 & 4.5 & \multicolumn{1}{c}{5.0} \\
\hline No. of donors $\ldots \ldots \ldots \ldots \ldots \ldots$ & 14 & 43 & 20 & \multicolumn{1}{c}{4} \\
\hline No. of embryos/donor $* \ldots \ldots$ & $9.6 \pm 2.0$ & $5.6 \pm 0.8$ & $4.2 \pm 0.8$ & $10.0 \pm 2.1$ \\
No. of viable embryos $\ldots \ldots$ & $4.3 \pm 1.3$ & $3.1 \pm 0.6$ & $2.7 \pm 0.6$ & $5.0 \pm 2.9$ \\
\hline p. 100 viable embryos $\ldots \ldots \ldots$ & 44.8 & 55.4 & 64.3 & 50.0
\end{tabular}

* Values indicate $\bar{x} \pm$ SEM.

Cloprostenol-estrus interval. - 82 out of 92 animals were in heat within $60 \mathrm{hrs}$ after the cloprostenol treatment. The mean interval was $45 \pm 7 \mathrm{hrs}$. It is obvious that estrus control was subject to error, but if the interval exceeded 48 hrs a significant drop in embryo number and quality appeared (table 7).

\section{TABLE 7}

Number and quality of embryos recovered non-surgically from loctating dairy cows on days $61 / 2-71 / 2$. Effect of prostaglandin treatment-estrus interval $(n=85)$.

\begin{tabular}{|c|c|c|c|c|}
\hline PG - estrus (hrs) $\ldots \ldots \ldots \ldots \ldots$ & 24-36 & $37-48$ & $49-60$ & $61-72$ \\
\hline No. of donors . . . . . . . . . . & 10 & 60 & 12 & 3 \\
\hline $\begin{array}{l}\text { No. of embryos/donor }{ }^{*} \ldots \ldots \\
\text { No. of viable embryos }{ }^{*} \ldots \ldots\end{array}$ & $\begin{array}{l}7.5 \pm 2.1 \\
4.1 \pm 1.2\end{array}$ & $\begin{array}{l}6.0 \pm 0.7 \\
3.3 \pm 0.5\end{array}$ & $\begin{array}{l}3.9 \pm 0.6 \\
1.6 \pm 0.6\end{array}$ & $\begin{array}{l}4.3 \pm 1.0 \\
0.7 \pm 0.5\end{array}$ \\
\hline p. 100 viable embryos ......... & 54.7 & 55.0 & 41.0 & 16.3 \\
\hline
\end{tabular}

* Values indicate $\bar{x} \pm S E M$.

Donor cow age. - Although the residual capacity of the ovary is very large, it could be expected that old donor cows (bull-dam) would give embryos of inferior quality, i.e. old age would be incompatible with good quality embryos. We studied this point; the main results are shown in table 8 . The highest number of embryos was recorded in the 4 to 5-year age group (11.5 embryos per donor and 5.7 viable embryos), and the second-best were the 5 to 6 -year old cows. Seven to 9-year old cows had the 
lowest total yield, but a relatively high fertility rate. Overall age of the donor cows was $66 \pm 38$ months (5.5 years). Hasler (1978) did not find any influence of age on the number of fertilized eggs.

TABLE 8

Number and quality of embryos recovered non-surgically from lactating dairy cows on days $61 / 2-71 / 2$. Effect of donor cow age $(n=75)$

\begin{tabular}{lcccccccc}
\hline Age of cow (years) $\ldots \ldots \ldots$ & $\leqslant 2.5$ & $3-4$ & $4-5$ & $5-6$ & $6-7$ & $7-9$ & $>9$ \\
\hline No. of donors $\ldots \ldots \ldots \ldots$ & 8 & 24 & 11 & 11 & 7 & 8 & 6 \\
\hline No. of embryos/donor * $\ldots$ & $4.6 \pm 1.4$ & $4.6 \pm 0.7$ & $11.5 \pm 2.4$ & $6.5 \pm 1.5$ & $4.4 \pm 1.4$ & $2.3 \pm 0.7$ & $4.7 \pm 1.2$ \\
\hline No. of viable embryos * $\ldots$ & $1.4 \pm 0.5$ & $2.6 \pm 0.6$ & $5.7 \pm 1.7$ & $3.5 \pm 1.4$ & $2.7 \pm 1.0$ & $2.0 \pm 0.5$ & $2.8 \pm 1.3$ \\
\hline p. 100 viable embryos $\ldots \ldots$ & 30.4 & 56.5 & 49.6 & 53.8 & 61.4 & 87.0 & 59.6 \\
\hline
\end{tabular}

* Values indicate $\bar{x} \pm$ SEM.

Number of calvings (parity). - Although we tried to use only animals that had calved normally and had no postpartum infection or metabolic disease, a large number of calvings might affect the embryo quality. The mean number of calvings was $3.6 \pm 1.9$; table 9 presents a survey of embryo number and quality in relation to

\section{TABLE 9}

Number and quality of embryos recovered non-surgically from lactating dairy cows on days $61 / 2-71 / 2$. Effect of number of calvings $(\mathbf{n}=86)$

\begin{tabular}{lcccccccc} 
No. of calvings $\ldots \ldots \ldots \ldots$ & 1 & 2 & 3 & 4 & 5 & 6 & $>6$ \\
\hline No. of donors $\ldots \ldots \ldots \ldots \ldots$ & 15 & 32 & 9 & 9 & 11 & 5 & 5 \\
\hline No. of embryos/donor * $\ldots$ & $5.5 \pm 1.1$ & $5.8 \pm 1.0$ & $11.8 \pm 2.7$ & $6.2 \pm 1.5$ & $4.2 \pm 1.0$ & $4.2 \pm 1.6$ & $5.2 \pm 1.5$ \\
\hline No. of viable embryos * $\ldots$ & $2.2 \pm 0.7$ & $3.2 \pm 0.1$ & $7.2 \pm 2.1$ & $2.9 \pm 1.4$ & $2.6 \pm 0.7$ & $3.2 \pm 1.0$ & $3.2 \pm 1.4$ \\
\hline p. 100 viable embryos $\ldots \ldots$ & 40.0 & 55.2 & 61.0 & 46.8 & 61.9 & 76.2 & 61.5
\end{tabular}

* Values indicate $\overrightarrow{\mathrm{x}} \pm \mathrm{SEM}$.

embryonic yield. 32 out of 76 donor animals had calved twice, but in the group with 3 calvings we observed a higher number of embryos (11.8) than in any other group. Animals with 6 or more calvings did not have a significantly lower number of embryos than animals with 1, 2, 4 or 5 calvings. Hence, it did not seem that more calvings adversely affected embryo quality.

Calving interval. - Only a small group had a previous calving interval of less than 325 days. The mean interval was $369 \pm 39$ days, and in 40 out of 63 animals it was from 326 to 366 days. Within this group, 366 to 385 appeared superior to any other 
interval (table 10). It was assumed that an extended calving interval would express fertilizability, but there did not seem to be any correlation between the actual length of the interval and the subsequent embryonic yield after ovarian stimulation.

TABLE 10

Number and quality of embryos recovered non-surgically from lactating dairy on days $61 / 2-71 / 2$.

Effect of previous calving interval $(n=63)$

\begin{tabular}{|c|c|c|c|c|c|c|c|c|}
\hline $\begin{array}{c}\text { Calving interval } \\
\text { (days) ........ }\end{array}$ & $<325$ & $326-345$ & $346-365$ & $366-385$ & $386-405$ & $406-425$ & 426.445 & $>446$ \\
\hline No. of donors .. & 4 & 14 & 15 & 11 & 7 & 5 & 2 & 5 \\
\hline $\begin{array}{l}\text { No. of embryos/ } \\
\text { donor } * \\
\text { No. of viable em- } \\
\text { bryos } * \ldots \ldots\end{array}$ & $\begin{array}{l}4.3 \pm 2.4 \\
0.3 \pm 0.2\end{array}$ & $\begin{array}{l}5.4 \pm 1.5 \\
3.2 \pm 1.1\end{array}$ & $\begin{array}{l}6.3 \pm 1.5 \\
3.1 \pm 0.8\end{array}$ & $\begin{array}{l}8.5 \pm 2.5 \\
6.5 \pm 1.7 \\
\end{array}$ & $\begin{array}{l}3.7 \pm 1.2 \\
3.0 \pm 1.1\end{array}$ & $\begin{array}{l}6.4 \pm 1.5 \\
3.4 \pm 1.1 \\
\end{array}$ & $\begin{array}{l}7.0 \pm 0.7 \\
5.0 \pm 0.7\end{array}$ & $\begin{array}{l}4.4 \pm 1.2 \\
2.4 \pm 1.1\end{array}$ \\
\hline $\begin{array}{l}\text { P. } 100 \text { viable em- } \\
\text { bryos } \ldots \ldots \ldots\end{array}$ & 7.0 & 59.3 & 49.2 & 76.5 & 81.1 & 53.1 & 71.4 & 54.5 \\
\hline
\end{tabular}

* Values indicate $\vec{x} \pm S E M$.

Several authors have speculated that the actual milk yield at the time of superovulation could have some effect on the outcome of superovulation and conceivably on the actual embryonic yield. The animals in this study were subdivided into groups according to milk yield at the previous control milking (table 11). The trend is not

TABLE 11

Number and quality of embryos recovered non-surgically from lactating dairy cows on days $61 / 2-71 / 2$. Effect of donor cow milk -yield $(\mathrm{n}=61)$

\begin{tabular}{llcccccc}
\hline Milk yield (liters). . . . & $10.0-14.9$ & $15.0-19.9$ & $20.0-24.9$ & $25.0-29.9$ & $30.0-34.9$ & $>35.0$ \\
\hline No. of donors $\ldots \ldots \ldots$ & $\ldots$ & 14 & 12 & 10 & 8 & 12 & 5 \\
\hline No. embryos/donor * $\ldots$ & $8.2 \pm 1.8$ & $3.6 \pm 0.9$ & $7.3 \pm 2.3$ & $4.9 \pm 1.4$ & $8.8 \pm 2.2$ & $5.6 \pm 2.1$ \\
No. of viable embryos * . & $4.0 \pm 1.1$ & $1.4 \pm 0.6$ & $5.2 \pm 1.6$ & $2.6 \pm 1.2$ & $4.6 \pm 1.5$ & $4.4 \pm 1.7$ \\
\hline P. 100 viable embryos $\ldots$ & 48.8 & 38.9 & .71 .2 & 53.1 & 52.3 & 78.6 \\
\hline
\end{tabular}

* Values indicate $\overline{\mathrm{x}} \pm \mathrm{SEM}$.

obvious, and even in the $>35$ I group more embryos were recovered than in the 15 to 19.9 I group. It cannot be concluded from these data that increased milk yield adversely influenced the quality and number of the embryos. The fat percentage in the milk was also examined and related to embryo recovery; although 4.60 to 5.59 p. 100 fat was associated with poor embryonic yield, no conclusion could be drawn as to the effect of milkfat production (table 12). 
Several batches of PMSG were tested in these dairy cows, and although some authors have implied that there could be a difference between batches in respect to corpus luteum number (Sreenan and Beehan, 1976), there was no evidence that one batch produced better quality embryos than any other.

TABLE 12

Number and qualify of embryos recovered non-surgically from lacto ting dairy cows on days $61 / 2-71 / 2$. Effect of milk fat p. $100(n=59)$.

\begin{tabular}{lccccc} 
Milk fat (p. 100) . . . . . . & $2.50-3.59$ & $3.60-4.59$ & $4.60-559$ & $5.60-6.59$ & $\geqslant 6.60$ \\
\hline No. of donors . . . . . . . & 12 & 22 & 4 & 14 & 7 \\
\hline No. of embryos/donor * . & $7.2 \pm 2.2$ & $7.7 \pm 0.4$ & $2.5 \pm 0.4$ & $5.6 \pm 1.7$ & $6.7 \pm 2.4$ \\
No. of viable embryos * .. & $3.1 \pm 1.4$ & $4.3 \pm 0.9$ & $1.0 \pm 0.5$ & $3.1 \pm 1.1$ & $4.3 \pm 1.9$ \\
\hline p. 100 viable embryos . . . & 43.1 & 55.8 & 40.0 & 55.4 & 64.2
\end{tabular}

* Values indicate $\bar{x} \pm S E M$.

Calving-superovulation interval. - Hasler (1978) found no evidence that the calving-superovulation interval (C-S) influenced the number of fertilized embryos. The mean C-S interval in the animals in this study was $125 \pm 84$ days (table 13). The ani-

TABLE 13

Number and quality of embryos recovered non-surgicallt from lactating dairy cows on days 6 1/2-7 1/2. Effect of calving-superovulation interval $(n=83)$

\begin{tabular}{ccccc}
\hline C-PMSG (days) & No. of donors & $\begin{array}{c}\text { No. of embryos/ } \\
\text { donor }\end{array}$ & $\begin{array}{c}\text { No. of viable } \\
\text { embryos } *\end{array}$ & $\begin{array}{c}\text { p. } 100 \text { viable } \\
\text { embryos }\end{array}$ \\
\hline $30-45$ & 7 & $2.4 \pm 0.9$ & $1.3 \pm 0.4$ & 54.2 \\
$46-60$ & 13 & $6.1 \pm 1.3$ & $2.5 \pm 0.7$ & 41.0 \\
$61-75$ & 5 & $3.8 \pm 1.4$ & $3.2 \pm 1.6$ & 84.2 \\
$76-90$ & 17 & $5.3 \pm 1.5$ & $3.4 \pm 0.9$ & 64.2 \\
$91-120$ & 16 & $4.1 \pm 0.8$ & $2.4 \pm 0.8$ & 58.5 \\
$121-150$ & 4 & $11.4 \pm 3.1$ & $5.9 \pm 2.2$ & 51.8 \\
$151-180$ & 3 & $6.7 \pm 2.2$ & $0.7 \pm 0.5$ & 10.4 \\
$181-240$ & 6 & $8.0 \pm 1.3$ & $4.3 \pm 1.1$ & 53.8 \\
$241-300$ & 5 & $11.4 \pm 3.8$ & $5.8 \pm 2.5$ & 50.9 \\
$301-360$ & 4 & $4.0 \pm 1.1$ & $2.0 \pm 1.2$ & 50.0 \\
& & & & \\
\hline
\end{tabular}

* Values indicate $\bar{x} \pm$ SEM.

mals have been divided according to the C-S interval. The table is extremely difficult to evaluate, but it does appear that the previously recommended practise of initiating superovulation before 80 to 90 days after calving, in order to avoid poor embryonic fertility rate, needs to be revised. It is recommended, however, not to initiate supero- 
vulation before days 30 to 40 since this may produce poor embryonic yield and poor postsuperovulatory fertility.

Seasonal influence. - Season may affect the outcome of embryo transplantation (fertility rate of embryos, superovulatory response) (Shea ef al., 1976 : others) ; this factor has been examined in this study (table 14). The months of October, Novem-

\section{TABLE 14}

Number and quality of embryos recovered non-surgically from lactating dairy cows on days $61 / 2-71 / 2$. Seasonal influence $(n=90)$

\begin{tabular}{lccccc}
\hline Season $\ldots \ldots \ldots \ldots \ldots \ldots \ldots \ldots$ & 1st quarter & 2nd quarter & 3rd quarter & 4th quarter \\
\hline No. of donors $\ldots \ldots \ldots \ldots \ldots \ldots$ & 22 & 32 & 28 & 8 \\
\hline No. of embryos/donor $* \ldots \ldots$ & $5.2 \pm 1.1$ & $6.1 \pm 1.1$ & $6.3 \pm 1.0$ & $7.3 \pm 1.7$ \\
No. of viable embryos ${ }^{*} \ldots \ldots \ldots$ & $2.6 \pm 0.8$ & $3.4 \pm 0.8$ & $3.2 \pm 0.7$ & $4.3 \pm 0.8$ \\
\hline p. 100 viable embryos $\ldots \ldots \ldots$ & 50.0 & 55.7 & 50.8 & 58.9 \\
\hline
\end{tabular}

* Values indicate $\bar{x} \pm$ SEM.

ber and December yielded more embryos of better quality than the other threequarters of the year. It is very likely that animal feeding and general health under Danish conditions is better at that time and may have contributed to the outcome.

\section{Conclusion.}

Embryonic number and quality were studied under farm conditions in lactating dairy cattle, stimulated with PMSG IM. The total number and the quality of the embryos were assessed by stereomicroscopic examination. Several factors which might influence embryonic yield were closely studied. The pattern was not consistent, and it was usually very difficult to draw any definite conclusion because of the relatively low number of animals and the considerable individual variation. Several factors concerned with the effect of lactation, age and number of calvings could not be retained in this study.

EEC Seminar on "Ovarian stimulation and egg quality in mammals », Luynes, France, octobre 1978.

Résumé. 92 vaches laitières d'âge moyen 5,5 ans ayant déjà vêlé 3,6 fois, dont la production journalière était de 23 litres au moment du traitement de superovulation ont été utilisées. Le précédent intervalle entre vêlages était de 369 jours ( 71 vaches) et l'intervalle vêlage-traitement a été de 126 jours. Les animaux reçurent une injection de PMSG (1 500 à $3000 \mathrm{UI}$; moyenne : 2 400) entre les jours 8 à 13 du cycle (moyenne 10,7 jours), suivie 48 à $60 \mathrm{~h}$ (moyenne : $52 \mathrm{~h}$ ) de $0,5 \mathrm{mg}$ de cloprostenol. L'intervalle entre PMSG ef l'estrus a été de 4,1 jours et à partir de l'administration de cloprostenol, de 45,5 h. En moyenne 6 embryons par donneuse a été collecté par voie non chirurgicale entre les jours 6 à 8 après 
l'estrus (moyenne : 7,1). 4 groupes d'œufs ont été identifiés : a) embryons (morula, blasfocyste, éclos ou non) de développement normal sans signe de dégénérescence, représentant 54,2 p. 100 , soit 3,3 par donneuse; $b$ ) embryons à développement retardé (5,8 p. 100 et 0,35 par donneuse) ; $c$ ) embryons manifestement en dégénérescence (morulas ou jeunes blastocystes) représentant 23,7 p. 100 du total et 1,4 par donneuse ; $d$ ) les œufs non fécondés (16,3 p. 100 et 0,88 par donneuse). 3000 UI de PMSG permettent d'obtenir un plus grand nombre d'embryons que 2500 ou 2000 (6,9, 5,8 5,9 respectivement), mais les deux plus faibles doses produisent un plus fort pourcentage d'embryons normaux. Un plus grand nombre d'embryons a été retrouvé dans la corne droiłe que dans la corne gauche et parallèlement un plus grand nombre de corps jaunes sur l'ovaire droit que sur l'ovaire gauche (7 et 2,$9 ; 4,1$ et 3,7 respectivement). Aucune différence n'a été observée selon les lots de PMSG. Le nombre d'embryons retrouvés varie selon le jour de l'injection au cours du cycle : 9e jour : 5,1 ; $10 \mathrm{e}$ jour : 6,$5 ; 11 \mathrm{e}$ jour : 6,$6 ; 12^{\mathrm{e}}$ jour : 7,$9 ; 13^{\mathrm{e}}$ jour : 6,1 . II existe également des différences dans le nombre d'embryons obtenus en fonction du délai PMSG/estrus : 3,5 jours : 9,6 embryons ; 4 jours : 5,6 embryons ; 4,5 jours : 4,2 embryons ( 4 animaux seulement ont présenté un intervalle de 5 jours avec en moyenne 10 embryons). 71 p. 100 des animaux entrèrent en estrus de 37 d̀ $48 \mathrm{~h}$ après le cloprostenol, fournissant en moyenne 6,0 embryons. Chez 11,8 p. 100 des animaux, l'estrus eut lieu plus tôt (24 à 36 h) et ils donnèrent 7,5 embryons. 14,1 p. 100 entrèrent en estrus plus tard ( 49 à $60 \mathrm{~h}$ ) et seulement 3,9 embryons furent récupérés. Aucune différence significative ne fut observée entre les races (Jersey et SDM). Un essai limité avec une race à viande a permis de collecter 7,1 embryons. Ainsi, ni l'âge, ni la parité, ni les intervalles vêlage-vêlage et vêlage-traitements ni le niveau de production laitière n'ont montré d'effet spécifique sur laproduction d'embryons. Bien qu'il existe des variations inter individuelles entre cornes utérines quant au nombre et à la qualité des embryons récupérés, en se basant sur 3 années d'expérience, on peut conclure qu'il existe une corrélation élevée entre l'évaluation morphologique de l'embryon et le taux de gestation.

\section{References}

BOUTERS R., DHONDT D., VANDEPLASSCHE M., CORYN M., 1976. Non-surgical recovery of bovine embryos. Vlaams diergeneesk, 45, 426-432.

BRAND A., TROUNSON A. O., AARTS M. H., DROST M., ZAAYER D., 1978. Superovulation and non-surgical embryo recovery in the lactating dairy cow. Anim. Prod., 26, 55-60.

CHURCH R. B., SHEA B., 1976. Some aspects of bovine embryo transfer, 73-86. EEC Seminar : Egg transfer in cattle. L. E. A. ROWSON. Comm. Eur. Commun., Luxembourg, EUR 5491.

DU MESNIL DU BUISSON F., RENARD J. P., LEVASSEUR M. C., 1976. Factors influencing the quality of ova and embryos. In Embryo transfer in farm animals. K. J. BETTERIDGE, Canad Dept. Agric. Monograph 16, 24-26.

ELSDEN R. P., NELSON L. D., SEIDEL G. E., Jr., 1978. Superovulating cows with follicular stimulating hormone and pregnant mare's serum gonadotrophin. Theriogenology, 9, 17-26.

GORDON I., 1975. Problems and prospects in cattle egg transfert. Irish vet. J., 29, 21-30 and 39-62.

GREVE T., LEHN-JENSEN H., 1977. Practical application of non-surgical embryo transplantation in valuable pedigree animals. Royal vet.-Agric. Univ., Steril. Res. Inst., Annu. Rep., 20, 1-24.

GREVE T., LEHN-JENSEN H., RASBECH N. O., 1977. Non-surgical recovery of bovine embryos. Theriogenology, 7, 239-251.

GREVE T., LEHN-JENSEN H., RASBECH N. O., 1978. Eitransplantation beim Rind. Nicht-chirurgisches Aufsammeln von Bovinen Embryonen in der Praxis. Tierarztl. Prax., 6, 313-324.

HAHN R., 1977. Personal communication.

HASLER J. F., 1978. Superovulation of the lactating cow. Theriogenology, 9, 94.

KARDYMOVICZ O., 1972. A method of vital staining for determining the viability of fertilized sheep ova Stored in vitro. Proc. 7 th inf. Congr. Anim. Reprod. A. I., Munchen, 1, 503-506.

LAMPETER W. E., 1977. Non-surgical recovery of bovine embryos under farm conditions. EEC Seminar: Control of reproduction in the cow. Galway, Ireland. 
NEWCOMB R., ROWSON L. E. A., TROUNSON A. O., 1976. The entry of superovulated eggs in the uterus, 1-15. In Egg transfert in caftle. L. E. A. ROWSON. Comm. Eur. Commun., Luxembourg, EUR 5491.

NEWCOMB R., CHRISTIE W. B., ROWSON L. E. A., 1977. The non-surgical recovery and transfer of bovine embryos. EEC Seminar : Control of reproduction in the cow. Galway, Ireland.

PHILIPPO M., ROWSON L. E. A., 1975. Prostaglandins and superovulations in the bovine. Ann. Biol. anim. Bioch. Biophys., 15, 233-246.

RENARD J.-P., MÉNÉZO Y., SAUMANDE J., HEYMANN Y., 1977. Attempts to predict the viabilify of cattle embryos produced by superovulation. EEC Seminar : Control of Reproduction in the cow. Galway, Ireland.

SEIDEL Jr. G. E., ELSDEN R. P., NELSON L. D., HASLER J. F., 1977. Methods of ovum recovery and factors affecting fertilization of superovulated bovine ova. EEC Seminar : Control of reproduction in the cow. Galway, Ireland.

SHEA B. F., HINES D. J., LIGHTFOOT D. E., OLLIS G. W., OLSON S. M., 1976. The transfer of bovind embryos, 145-152. In Egg transfer in caftle, L. E. A. ROWSON. Comm. Eur. commun., Luxembourg, EUR 5491.

SREENAN J. M., BEEHAN D., 1976. Methods of induction of superovulation in the cow and transfer results, 19-34. In ROWSON L. E. A., Egg transfer in cattle, Comm. Eur. Commun., Luxemburg, EUR 5491.

TROUNSON A. O., WILLADSEN S. M., ROWSON L. E. A., NEWCOMB R., 1976. The storage of the cow eggs at room temperature and low temperature. J. Reprod. Fertil., 46, 173-178.

WHITTINGHAM D. G., 1978. Viability assays for mammalian ova. Cryobiology, 15, 245-248. 